\title{
Molten Carbonate Fuel Cell Program Progress Report for Period April 1-June 30, 1978
}
J. Braunstein
H. R. Bronstein
S. Cantor
J. I. Padova 


\section{DISCLAIMER}

This report was prepared as an account of work sponsored by an agency of the United States Government. Neither the United States Government nor any agency Thereof, nor any of their employees, makes any warranty, express or implied, or assumes any legal liability or responsibility for the accuracy, completeness, or usefulness of any information, apparatus, product, or process disclosed, or represents that its use would not infringe privately owned rights. Reference herein to any specific commercial product, process, or service by trade name, trademark, manufacturer, or otherwise does not necessarily constitute or imply its endorsement, recommendation, or favoring by the United States Government or any agency thereof. The views and opinions of authors expressed herein do not necessarily state or reflect those of the United States Government or any agency thereof. 


\section{DISCLAIMER}

Portions of this document may be illegible in electronic image products. Images are produced from the best available original document. 
Printed in the United States of America. Available from National Technical Information Service

U.S. Department of Commerce

5285 Port Royal Road, Springfield, Virginia 22161

Price: Printed Copy $\$ 4.50 ;$ Microfiche $\$ 3.00$

This report was prepared as an account of work sponsored by an agency of the United States Government. Neither the United States Government nor any agency thereof, nor any of their employees, contractors, subcontractors, or their employees, makes any warranty, express or implied, nor assumes any legal liability or responsibility for any third party's use or the results of such use of any information, apparatus, product or process disclosed in this report, nor represents that its use by such third party would not infringe privately owned rights. 
ORNL/TM-6168/V4

Dist. Category UC-4

Contract No. W-7405-eng-26

\title{
CHEMISTRY DIVISION
}

MOLTEN CARBONA'I'E FUEL CELL PROGRAM

PROGRESS REPORT FOR PERIOD APRIL 1-JUNE 30, 1978
J. Braunstein
H. R. Bronstein
S. Cantor

J. I. Padova

Date Published - September 1978

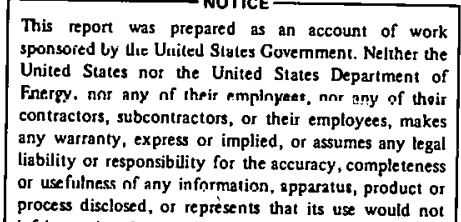

NOTICE This document contains information of a preliminary nature. It is subject to revision or correction and therefore does not represent a final report.

\author{
OAK RIDGE NATIONAL LABORATORY \\ Oak Ridge, Tennessee 37830 \\ operated by \\ UNION CARBIDE CORPORATION \\ for the \\ DEPARTMENT OF ENERGY
}




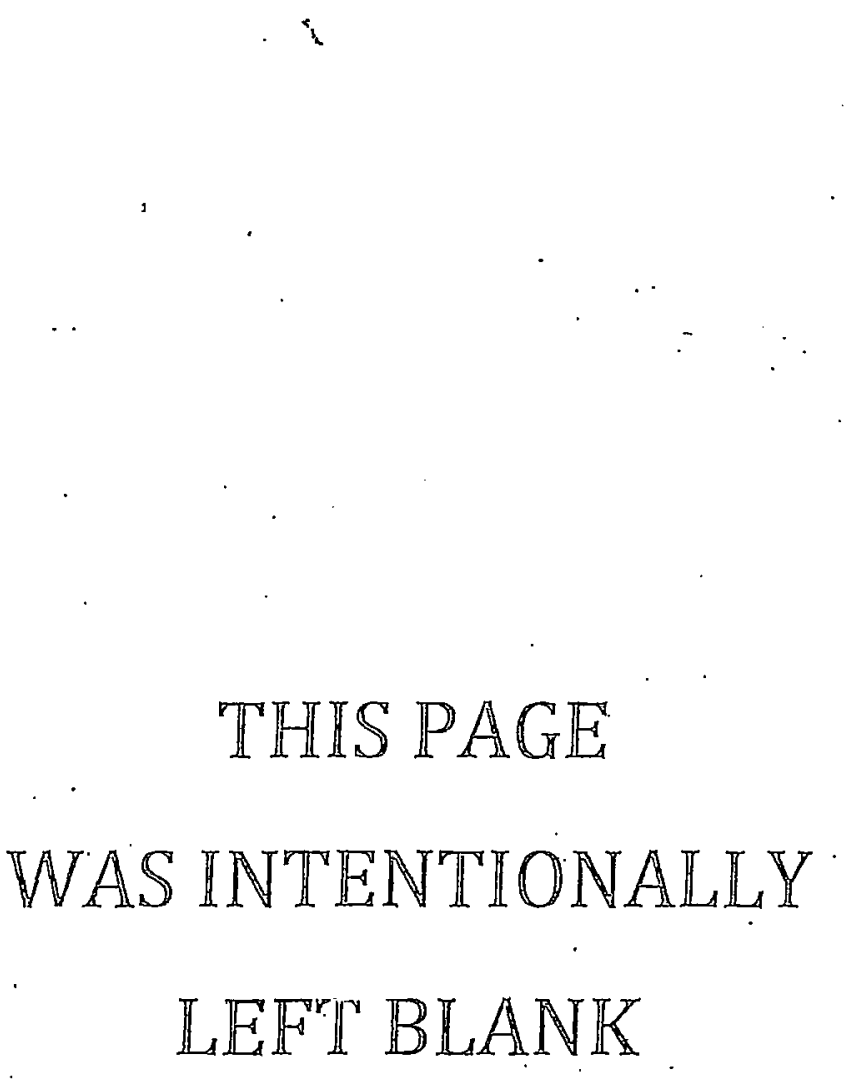


CONTENTS

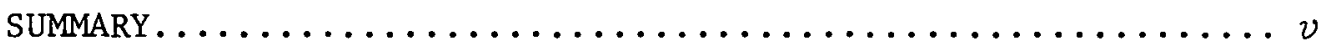

I. Electrolysis and EMF Relaxation in Molten Carbonate

Fuel Cell Tiles and Electrodes................... 1

II. Activity Coefficients in Isothermal $\mathrm{Li}_{2} \mathrm{CO}_{3}-\mathrm{K}_{2} \mathrm{CO}_{3}$ Mixtures.... 15

III. NiO Electrode Studies....................... 18 
i

THIS PAGE

WAS INTENTIONALLY

LEFT BLANK 


\section{SUMMARY}

Progress was made in the measurement and interpretation of emf relaxations following electrolysis of molten carbonate fuel cell tiles. An extensive series of measurements was carried out at $610^{\circ} \mathrm{C}$ at current densities from 29 to $285 \mathrm{~mA} / \mathrm{cm}^{2}$ and for electrolysis times of from five minutes to two hours. 'lhe observed decay of emf shows relaxation on three time scales: an initial rapid decay on the time scale of double layer relaxation, followed by a decay of the order of 10 minutes to an hour, characteristic of liquid state diffusion, and finally a very slow decay (hours to days) which may be related to solid state effects in the electrodes. The mass transport model provides a satisfactory representation of the intermediate relaxation.

Computation of the composition dependence of the activity coeffi'cients in $\mathrm{Li}_{2} \mathrm{CO}_{3}-\mathrm{K}_{2} \mathrm{CO}_{3}$ was initiated using the phase diagram, the heats of mixing and a new method for obtaining the derivative of the activity coefficients without the need for extrapolation and evaluation of unnecessary integration constants. This derivative is needed in the interpretation of both the free electrolyte transference cell measurements and the emf relaxation measurements to determine relative mobilities of lithium and potassium.

Slow penetration of $\mathrm{Li}^{+}$into massive samples of $\mathrm{NiO}$ indicated the need for thinner samples in studies of lithiation of NiO under fuel cell conditions and for the preparation of lithiated NiO electrodes of known area. A series of equilibrations in $\mathrm{Li}_{2} \mathrm{CO}_{3}-\mathrm{K}_{2} \mathrm{CO}_{3}$ under $\mathrm{CO}_{2}-\mathrm{O}_{2}$ atmospheres is being carried out with single crystal wafers ground and polished to a thickness of $0.01 \mathrm{~cm}$. 
I. Electrolysis and EMF Relaxation in Molten Carbonate Fuel Cell Tiles and Electrodes (J. I. Padova, H. R. Bronstein and J. Braunstein)

The performance and lifetime of molten carbonate fuel cells are affected by the composition and stability of the electrolyte. Among the physical properties affecting the behavior of the fuel cell electrolytes are the transport properties ${ }^{(1)}$ and it is the purpose of this work to provide information and understanding on these properties in molten carbonates. Computations $(2,3,4)$ have indicated that if there are significant differences between the electrical mobilities of the cations in mixad alkali carbonate fuel cell electrolytes, appreciable concentration gradients may be expected to develop in the electrolyte under high current density operation. These gradients could be sufficlent to lead to precipitation of $\mathrm{Li}_{2} \mathrm{CO}_{3}$ or $\mathrm{K}_{2} \mathrm{CO}_{3}$ at one of the electrodes (3).

Here we summarize the results of experiments on the electrolysis of molten fuel cell tiles and electrodes. The experiments consist of electrolysis of a Li $2 \mathrm{CO}_{3}-\mathrm{K}_{2} \mathrm{CO}_{3}-\mathrm{LiAlO}_{2}$ fuel cell tile between oxidized nickel electrodes at a known current for a known perlod of time. The potential difference between the electrodes is measured at the cessation of electrolysis. Then the decay or relaxation of this open circuit potential back to its initial value is monitored as a function of time. If the gas composition and electrodes remain unchanged, the potential difference can be related to composition changes at the electrodes. That is, the emt is that of a concentration cell with transference, and provides a potentiometric measurement of the concentration gradient in the electrolyte between the electrodes. Although a direct chemical analysis of the concentration is desirable, and is being developed, difficulties with sufficiently rapid cooling of a cell assembly to prevent mixing, difficulties with sampling and with the analytical methods themselves (chemical, SEM) make the in situ potentiometric measurement valuable. Advantages of the electrolytic experiment over a fuel cell configuration include: 1 . Although the composition changes may be quite significant, their effect on the emf is not large, and might be hidden in emf fluctualions resulting from variations of gas composition 
in a fuel cell configuration; 2 . Since the electrodes are nearly identical, the emf change is measured relative to a small bias potential rather than relative to a varying fuel cell potential of nearly 1 volt; 3 . Measuring the emf between the two nearly identical electrodes eliminates uncertainties resulting from the use of reference electrodes whose accuracy and reproducibility in the tiles has not been demonstrated.

Our results show that the magnitude of the emf following electrolysis and its rate of decay are conststent with predlcted cumpusition changes ${ }^{(3)}$ at the electrodes resulting from mass transport effects in the electrolyte-electromigration and Interdiffusion of the two different kinds of cation $\mathrm{Li}^{+}$and $\mathrm{K}^{+}$in the electrolyte.

Figure T.I shows the analogy between the ion flows and electrode reactions in the fuel cell and in the electrolytic cell. In the fuel cell with a mixture of alkali carbonates $\left(\mathrm{Li}_{2} \mathrm{CO}_{3}-\mathrm{K}_{2} \mathrm{CO}_{3}\right)$ as electrolyte and with $\mathrm{CO}_{2} / \mathrm{O}_{2}$ as oxidant gas and $\mathrm{CO}_{2} / \mathrm{CO}$ or $\mathrm{CO}_{2} / \mathrm{H}_{2}$ as fuel gas, the cathode reaction produces carbonate and the anode reaction consumes carbonate. Similarly in the electrolytic cell, the cathode reaction produces carbonate ion and in the reverse reaction at the anode $\mathrm{CO}_{2}$ is produced. In both cells $\mathrm{CO}_{2}$ enters the electrolyte as $\mathrm{CO}_{3}{ }^{3-}$ and leaves at the anode. (The electrodes thus behave as membranes permeable to carbonate ions but impermeable to $\mathrm{Li}^{+}$or $\mathrm{K}^{+}$.) Relative to $\mathrm{CO}_{3}{ }^{2-}$ in the electrolyte, the current is carried by the cations; the more mobile ion (probably $\mathrm{Li}^{+}$) tends to accumulate at the cathode in accord with the flow equallums.

A concentration cell with transference is established by the balance of migrational and diffusion flows, and the corresponding emf is (2)

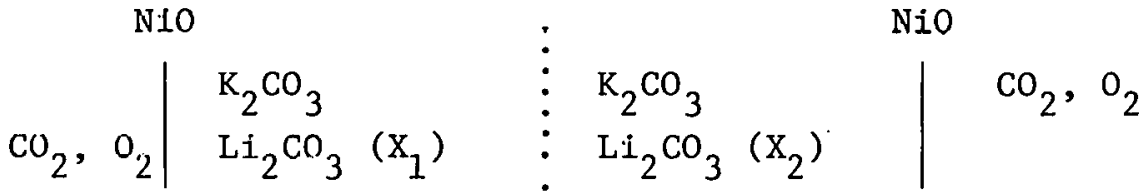

$$
\begin{aligned}
& -2 \mathrm{FE}=\int_{\mathrm{X}_{1}}^{\mathrm{X}_{2}} \frac{\mathrm{t}_{\mathrm{Li}}^{\mathrm{c}}+-\mathrm{x}_{\mathrm{Li}_{2} \mathrm{CO}_{3}}}{1-\mathrm{x}_{\mathrm{Li}_{2} \mathrm{CO}_{3}}} d \mu \mathrm{Li}_{2} \mathrm{CO}_{3}
\end{aligned}
$$


FUEL CELL

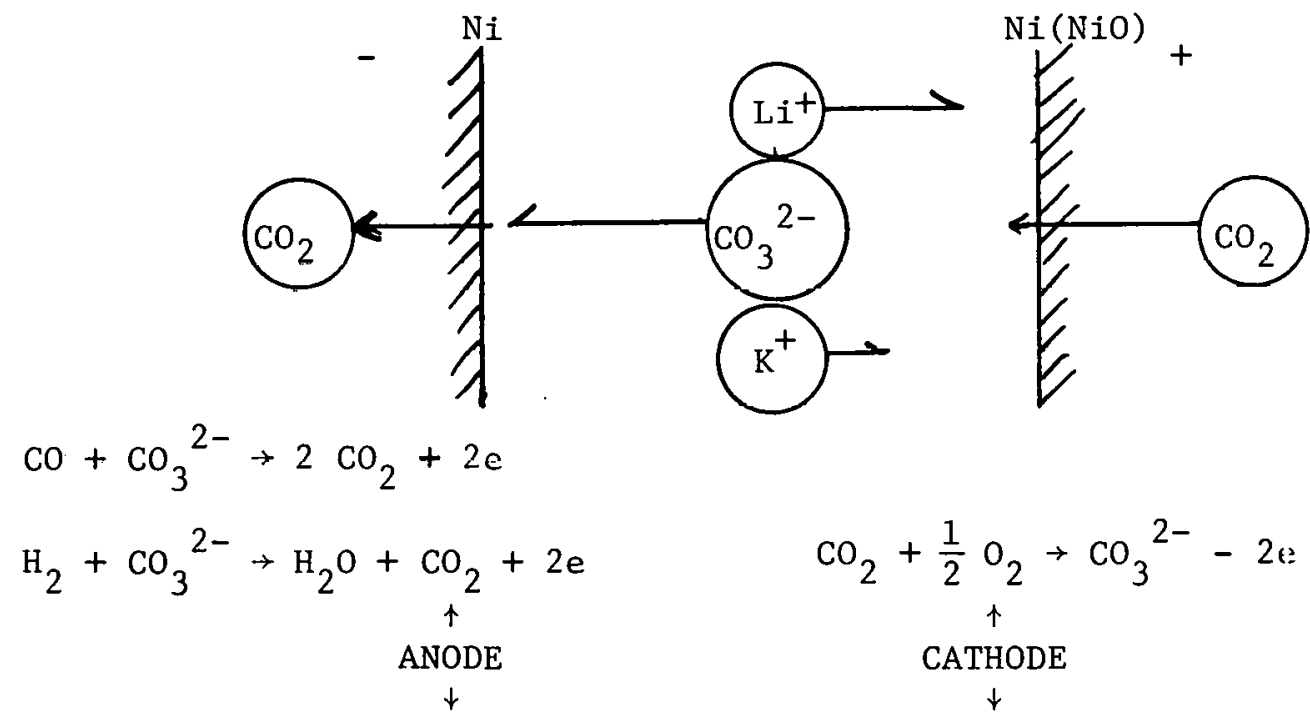

ELECIROLYSIS CELL

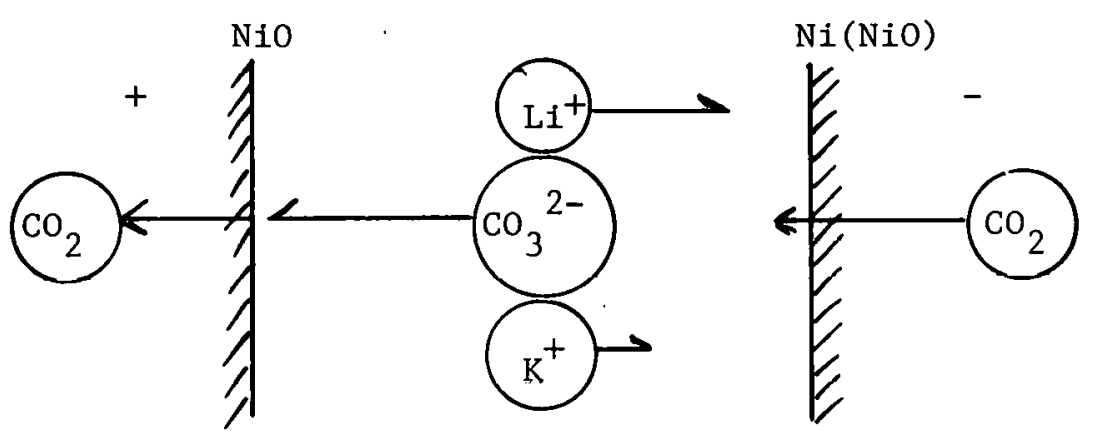

$$
\mathrm{CO}_{3}{ }^{2-} \rightarrow \mathrm{CO}_{2}+\frac{1}{2} \mathrm{O}_{2}+2 \mathrm{e}
$$

$$
\mathrm{CO}_{2}+\frac{1}{2} \mathrm{O}_{2} \rightarrow \mathrm{CO}_{3}{ }^{2-}-2 \mathrm{e}
$$

$$
\begin{aligned}
& \mathrm{J}_{\mathrm{Li}^{+}}+\left(\mathrm{t}_{\mathrm{Li}}^{\mathrm{c}}+-\mathrm{X}_{\mathrm{Li}}+\right) \mathrm{I} / \mathrm{F} \cdots \mathrm{D} \frac{\partial \mathrm{C}_{\mathrm{Li}^{+}}}{\partial \xi} \\
& \mathrm{J}_{\mathrm{K}^{+}}=\left(\mathrm{t}_{\mathrm{K}^{+}}^{\mathrm{c}}-\mathrm{X}_{\mathrm{K}^{+}}\right) \mathrm{I} / \mathrm{F}-\mathrm{D} \frac{\partial \mathrm{C}_{\mathrm{K}^{+}}}{\partial \xi}
\end{aligned}
$$

Fig. I.I Electrode reactions and ion flows. 
$t$ is transference number, or fraction of current carried by Lit relative to $\mathrm{CO}_{3}{ }^{2-}, \mathrm{X}_{\mathrm{Li}_{2} \mathrm{CO}_{3}}$ is the mole fraction of $\mathrm{Li}_{2} \mathrm{CO}_{3}$ in the mixture, I the current density, $D$ the interdiffusion coefficient, $C$ the volume concentration of $\mathrm{Li}^{+}$or $\mathrm{K}^{+}$. If the $\mathrm{Li}^{+}$and $\mathrm{K}^{+}$mobilities were equal, $\mathrm{t}_{\mathrm{Li}}^{+}=$ $\mathrm{X}_{\mathrm{Li}_{2} \mathrm{CO}_{3}}$. There would then be no separation of $\mathrm{Li}^{+}$from $\mathrm{K}^{+}$in the flow equations, no concentration cell and no emf. $\mu$ is the chemical potential of $\mathrm{Li}_{2} \mathrm{CO}_{3}$ in the $\mathrm{Li}_{2} \mathrm{CO}_{3}-\mathrm{K}_{2} \mathrm{CO}_{3}$ mixture and includes any activity coefficient correction. This is not well known but may be estimated from heat of mixing data.

In order to test the computations as well as to obtain direct experimental measurements of changes occurring in the electrolyte and the electrodes, an electrolytic apparatus was designed and constructed. (5) as illustrated in Fig. I.2.

Description of the Apparatus.

The carbonate tile (No. 13), supplied by Dr. J. Ackerman of Argonne National Laboratory, is a disk about $0.2 \mathrm{~cm}$ thick and $2 \mathrm{~cm}$ in diameter with a composition of 50 weight per cent of equimolar $\mathrm{Li}_{2} \mathrm{CO}_{3}-$ $\mathrm{K}_{2} \mathrm{CO}_{3}$ and 50 weight per cent of $\mathrm{LiAlO}_{2}$. The t1le is compressed between the sintered nickel disk electrodes (No. 12) by means of perforated stainless steel current collectors (No. 11), where the two parts are bolted together. The perforations permit gas flow to the N1-N10 electrodes. Numbers 3 and 4 are the thermocouple well and thermocouple for monitoring the temperature at the electrode. Number 1 is a gold reference electrode.

The porous nickel disks were preconditioned and oxidized in situ at $873^{\circ} \mathrm{K}$ with a $66-34$ volume per cent mixture of $\mathrm{CO}_{2}$ and $\mathrm{O}_{2}$ to convert them to Ni-Nio electrodes for the electrolysis reaction

$$
\mathrm{CO}_{2}+\frac{1}{2} \mathrm{O}_{2}+\mathrm{e}^{-} \underset{\text { anodic }}{\stackrel{\text { cathodic }}{\gtrless}} \mathrm{CO}_{3}{ }^{2-}
$$

A constant electrolysis current was supplied by a PAR potentiostatgalvanostat-coulometer operated in the galvanostatic mode. After termination of the electrolysis at a fixed current for a fixed time the open 


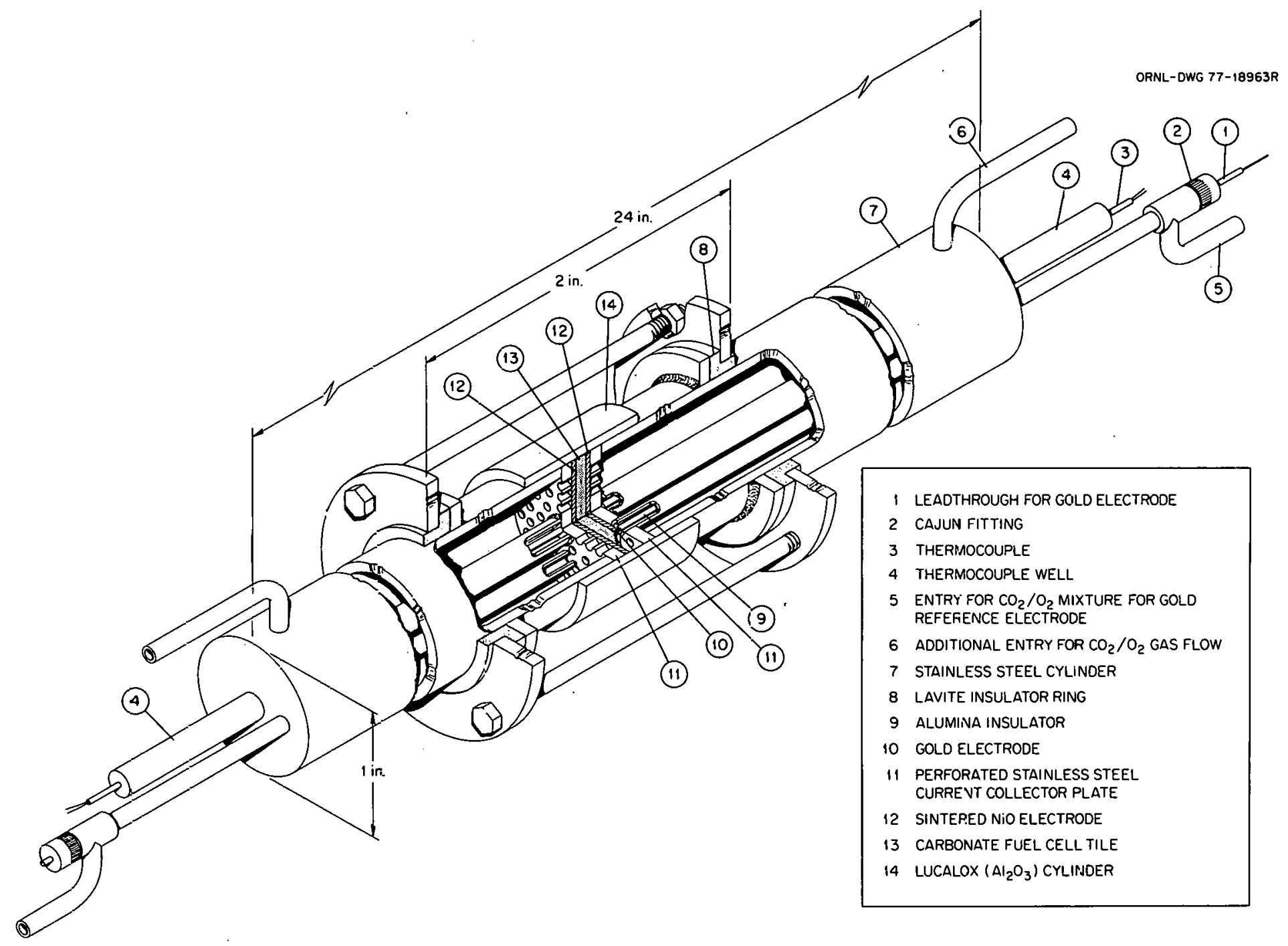

Fig. I.2 Cell for electrolysis of $\mathrm{Li}_{2} \mathrm{CO}_{3}-\mathrm{K}_{2} \mathrm{CO}_{3}-\mathrm{LiAlO} \mathrm{O}_{2}$ tiles between $\mathrm{Ni}$ (NiO; electrodes under $\mathrm{CO}_{2}-\mathrm{O}_{2}$ atmosphere, and measurement of emf relaxation after current flow. 
circuit potential between the two electrodes was monitored with time. The relaxation of the emf following electrolysis was systematically studied over a wide range of current densities and electrolysis duration. Table I.I shows some of the results obtained at a constant current density of $200 \mathrm{~mA} / \mathrm{cm}^{2}$ when the electrolysis time varied from 5 minutes to 100 minutes. The first column lists the difference in potential between the two electrodes referred to the equilibrium open circuit potential 30 seconds after cessation of electrolysis. This period of time is assumed, somewhat arbitrarily, to allow for double layer relaxation to be compleced. It may be secn that the values nf $\Delta E$ increase steadily with duration of electrolysis up to 60 minutes and then seem to decrease slightly. The last column shows the time needed for the emf to relax to half the initial value. I'his relaxation time $\tau_{1 / 2}$ seems to be approximately constant, 10 minutes, except for cases where electrolysis was carried out longer than 60 minutes.

Table I.2 shows the data obtained at a constant electrolysis time but at various current densities. The left column lists the magnitude of the open circuit potential at cessation of a 60 minute electrolysis, referred again to the potential at equilibrlum. The second column gives the nominal current density of each experiment whilc in the right rnlumn the emf half time values are listed correspondingly. Again, the emf increases with current densities, and the time at which it reaches half its initial value is very near ten minutes except for the last case described.

These data are illustrated in the experimental curves shown in Figs. I. 3 and I.4, where the increase of the emf at end of electrolyals is seen to increase with current density and electrolysis time.

A model for transport processes in molten ealt fuel cellis and batteries ${ }^{(2)}$ has been applied to the computation and simulation of relaxation processes taking place in molten carbonate fuel cells $(2,3)$. The results of the computation are illustrated by comparison between calculated curves and experimental points. A typical example is shown in Fig. I.5. The current density is $I=200 \mathrm{~mA} / \mathrm{cm}^{2}$ and the electrolysis time is 20 minutes. The theoretical concentrations are calculated 
Table I.1. EMF 30 seconds after cessation of electrolysis at $200 \mathrm{~mA} / \mathrm{cm}^{2}$ and time required $(\tau / 12)$ to relax to half that value 
Table I.2. EMF after electrolysis for 60 minutes at differing current densities and relaxation time $\left(\tau_{1 / 2}\right)$ to relax to half that
value

\begin{tabular}{ccc}
$\Delta \mathrm{E}_{\odot} / \mathrm{mV}$ & & \multicolumn{1}{c}{$\tau_{1 / 2} / \mathrm{min}$} \\
5.0 & 28.6 & 10.1 \\
5.5 & 57.1 & 9.9 \\
5.1 & 85.7 & 9.8 \\
6.9 & 114.3 & 9.9 \\
8.1 & 142.9 & 9.6 \\
8.7 & 171.4 & 10 \\
10.3 & 200 & 10.1 \\
11.3 & 228.6 & 10.0 \\
12.7 & 257.1 & 10 \\
10.7 & 285.4 & 9.8
\end{tabular}


ORNL-DWG. $78-16513$

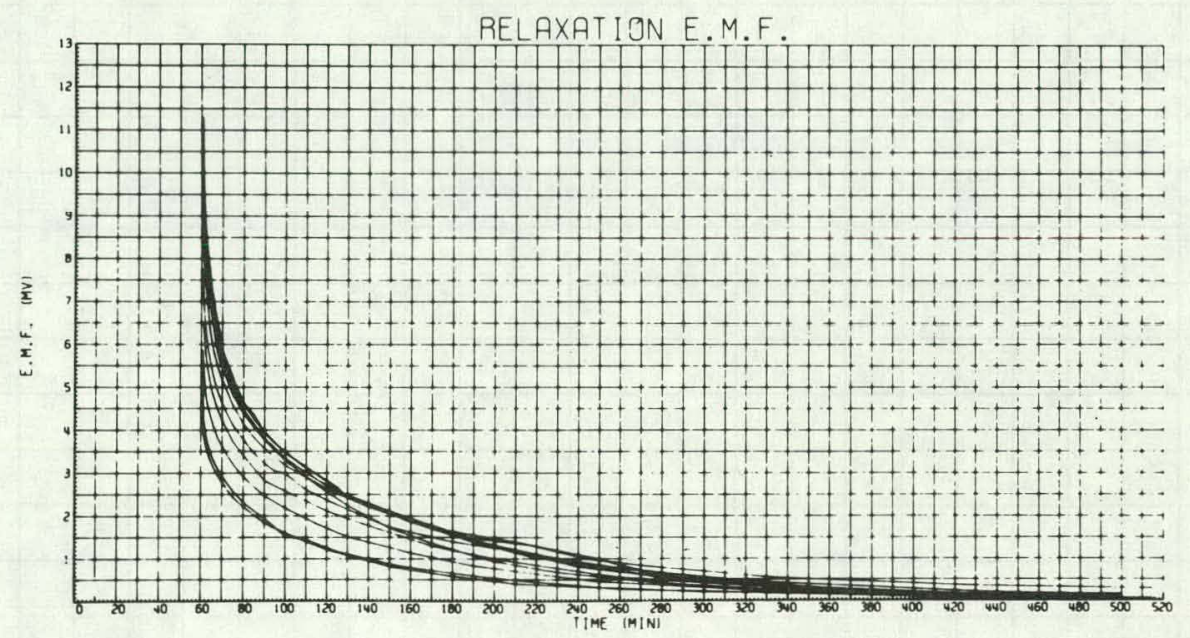

Fig. I.3 Effect of current density on open circuit potential difference between electrodes following electrolysis for 60 minutes. Current densities during electrolysis, $\mathrm{mA} / \mathrm{cm}^{2}: 28.6$ (lowest curve), 51, 86, 114, 143, 171, 200, 229, 257, 286 (upper curve).

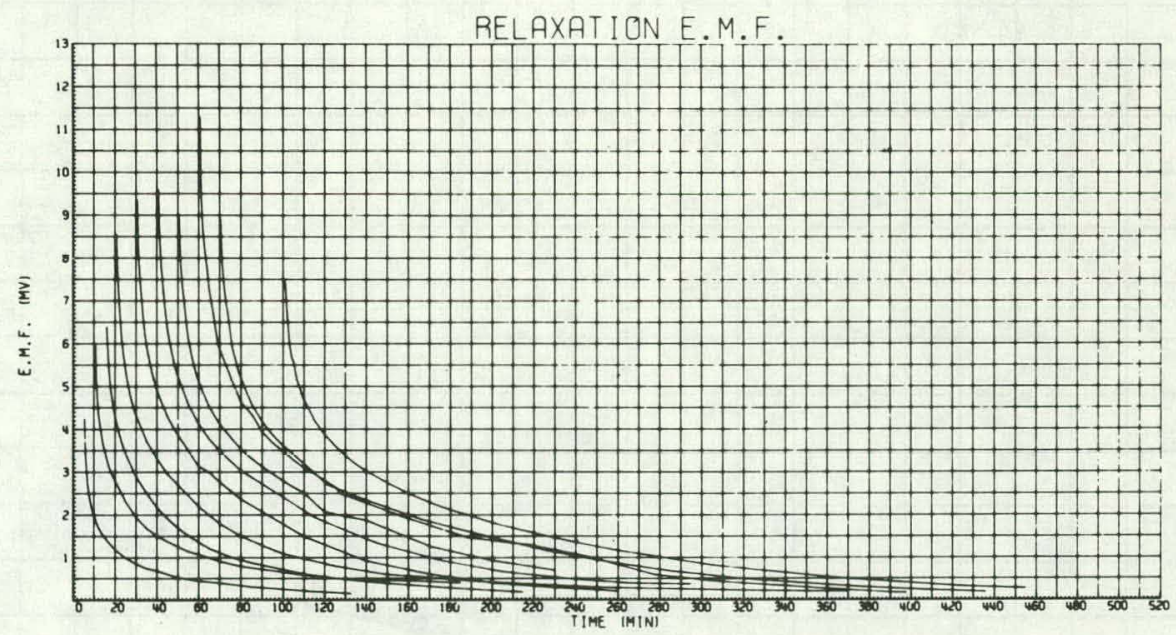

Fig. I.4 Effect of electrolysis time at fixed current density $200 \mathrm{~mA} / \mathrm{cm}^{2}$ on open circuit potential difference after electrolysis. 
ORNL-DWG. 78-16514

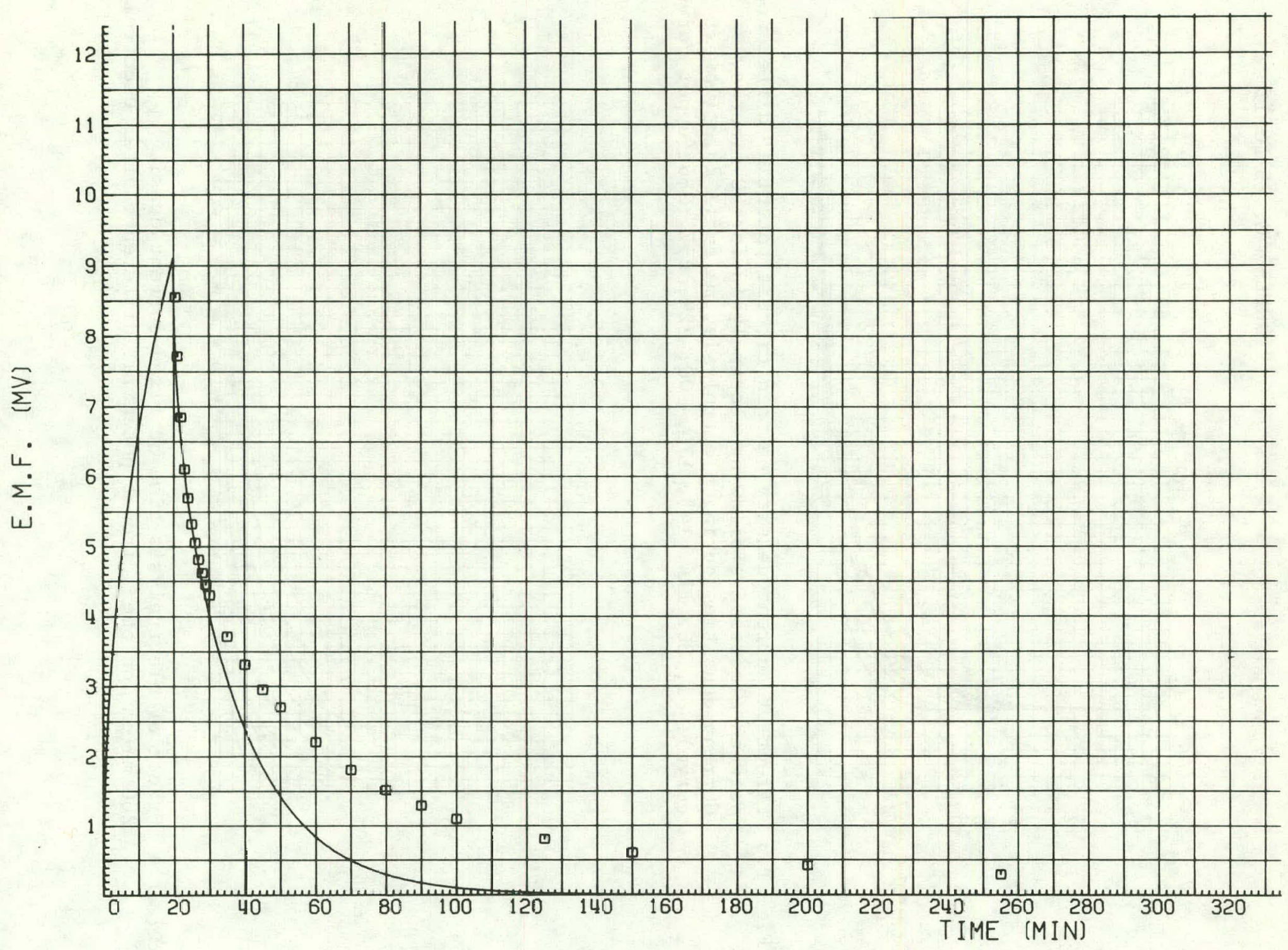

Fig. I.5 EMF relaxation. 
from a numerical solution of the diffusion migration equation based on electromigration and interdiffusion of the cations (4). and converted to the emf of the corresponding concentration cell. In the computation the interdiffusion coefficient was taken as $D=3.510^{-6} \mathrm{~cm}^{2} / \mathrm{s}$. This value of $D$ probably is low for free electrolyte, but is probably not far from the correct value in the porous matrix. The ratio of the mobilities of $\mathrm{Li}^{+}$and $\mathrm{K}^{+}$was taken as $\mathrm{U}_{\mathrm{Li}} / \mathrm{U}_{\mathrm{K}}=1.45$. The left part of the curve shows the theoretical building up towards a steady state concentration and emf. This rise and levelling off should correspond to the envelope of the curves of emf at cessation of electrolysis, experimental values of which are shown in Fig. I.4 and Table I.1. The slight downturn seen experimentally is not predicted by the model and may correspond to other electrode processes.

The predicted relaxation curve follows closely the experimental points for about 10 minutes, time at which half the value of the initial potential difference (referred to the open circuit potential) is reached. Thereafter the computed curve relaxes much faster than the experimental emf .

Similar behavior is observed for data obtained at other current densities and times in the range shown in Tables I.I and I.2. The mobility ratios required to reproduce the first ten minutes of the experimental relaxation curves with $\mathrm{D}=3.5 \times 10^{-6}$ are shown in Table I.3. The required mobility ratio decreases as the current density increases but remains of a magnitude which is physically reasonable. Since the mobility ratios should not be functions of current density, this apparent variation may reflect composition dependence both of mobilities and of diffusion coefficlents, convection, and other uncertainties in the model such as neglect of porosity of the electrodes and neglect of thermal effects at the electrodes. Fitting of the model to the relaxation data at very long times would require a much lower value of the interdiffusion coefficient, of the order of $1.2 \times 10^{-6}$. Thus, the long term relaxation may be the result of other processes, perhaps involving solid state changes in the NiO electrodes.

In summary, emf-time curves following electrolysis show relaxations 
Table I.3. Mobility ratios needed for fit of model to initial relaxation (10-15 minutes) with $\mathrm{D}=3.5 \times 10^{-6}$

$$
\underset{\mathrm{mA} / \mathrm{cm}^{2}}{\text { Current density }}
$$

28.6

57.1

85.7

114.3

142.9

171.4

200.0

228.6

257.1

285.4
Mobility ratio

$\mathrm{U}_{\mathrm{Li}} / \mathrm{U}_{\mathrm{K}}$

2.05

1.68

1.6

1.55

1.5

1.5

1.5

1.45

1.45

1.38 
on three different time scales: a rapid drop from the voltage during electrolysis ( 1 volt) to a value of the order 5 to 15 millivolts in a period of the order of seconds (probably IR drop and decay of the double layer); a decay to about a millivolt in a time of the order of several minutes, characteristic of diffusion in the tile; and finally, a decay of hours or days back to the potential difference between the electrodes prior to electrolysis, possibly related to solid state changes in the electrodes. Further studies of mass transport in molten carbonate tiles are under way to elucidate the electrochenical behavior of electrolytes and clectrodes. 


\section{References}

(1) J. R. Selman, H. C. Maru, V. Sampath and L. G. Marianowski, "Partial Processes and Transport Parameters in Molten Carbonate Fuel Cell Operation," Proc. Symp. Electrode Materials and Processes for Energy Conversion and Storage, The Electrochemical Society, Vol. 77-6, Princeton, NJ, pp. 656-681 (1977).

(2) J. Braunstein and C. E. Vallet, "Migrational Polarization in High Current Density Molten Salt Electrochemical Devices," Pruc. 3ymp. Electrode Materials and processes for Einergy Convereion and Storage, The Electrochemical Society, Vo1. 77-6, Princcton, NJ, pp. 559-571 (1977).

(3) J. Braunstein, H. R. Bronstein, S. Cantor, D. E. Heatherly, L. D. Hulett, R. L. Sherman, C. E. Vallet and G. Watts, "Molten Carbonate Fuel Cell Research at. ORNL. II.," ORNL Rept. ORNL/TM6168/V2, Dec. 1977, pp. 1-6.

(4) C. E. Vallet and J. Braunstein, "Solution of Electrochemical Flux Equations with Variable Diffusion Coefficient and Transference Number," J. Phys. Chem. 81, 2438-43 (1977).

(5) J. Braunstein, H. R. Bronstein, J. I. Padova and C. E. Vallet, "Molcen Carbunate Fucl Cell Program Prngress Repurt for Pcriods Ending October 1-December 31, 1977; January 1-March 31, 1978," ORNL Rept. ORNL/TM-6168/V3. 
II. Activity Coefficients in Isothermal $\mathrm{Li}_{2}{ }_{-} \mathrm{CO}_{3}-\mathrm{K}_{2}{ }_{2} \mathrm{CO}_{3}$ Mixtures

Activity coefficients in molten carbonate mixtures are needed for the evaluation and interpretation of chemical equilibria, phase equilibria and transport properties of importance in molten carbonate fuel cells. The $\mathrm{Li}_{2} \mathrm{CO}_{3}-\mathrm{K}_{2} \mathrm{CO}_{3}$ phase diagram and heats of fusion of $\mathrm{Li}_{2} \mathrm{CO}_{3}$ and $\mathrm{K}_{2} \mathrm{CO}_{3}(1,2)$ permit estimates of the activity coefficient of $\mathrm{Li}_{2} \mathrm{CO}_{3}$ at $\mathrm{Li}_{2} \mathrm{CO}_{3}$-rich compositions and of $\mathrm{K}_{2} \mathrm{CO}_{3}$ at $\mathrm{K}_{2} \mathrm{CO}_{3}-\mathrm{rich}$ compositions. Estimation of the activity coefficients of both components over extended composition ranges encompassing fuel cell electrolyte compositions requires cumbersome computations, even using the available heat of mixing data ${ }^{(3)}$. We have initiated calculations of the activity coefficients by a simplified method especially applicable to the case where only the composition dependence rather than the absolute values of the activity coefficients are needed. Such a case is the interpretation of the emf of the free electrolyte concentration cell, and of the concentration gradient which may be established at high current densities as a result of electrical mobility differences between $\mathrm{Li}^{+}$and $\mathrm{K}^{+}$relative to $\mathrm{CO}_{3}{ }^{2-(4,5)}$.

$$
\begin{aligned}
& \mathrm{Ni}, \mathrm{NiO}, \mathrm{CO}_{2}, \mathrm{O}_{2}\left|\mathrm{Li}_{2} \mathrm{CO}_{3}-\mathrm{K}_{2} \mathrm{CO}_{3}: \mathrm{Li}_{2} \mathrm{CO}_{3}-\mathrm{K}_{2} \mathrm{CO}_{3}\right| \mathrm{CO}_{2}, \mathrm{O}_{2}, \mathrm{NiO}, \mathrm{Ni} \\
& \mathrm{x}_{1} \quad \mathrm{x}_{2} \\
& E=-\frac{1}{2 F} \int_{X_{\perp}}^{\mathrm{X}_{2}} \frac{\mathrm{t}_{\mathrm{Li}}-\mathrm{X}_{\mathrm{Li}_{2} \mathrm{CO}_{3}}}{1-\mathrm{X}_{\mathrm{Li}_{2} \mathrm{CO}_{3}}}\left(\frac{\partial \mu_{\mathrm{Li}_{2} \mathrm{CO}_{3}}}{\partial \mathrm{X}_{\mathrm{Li}_{2} \mathrm{CO}_{3}}}\right)_{\mathrm{T}} d \mathrm{x}_{\mathrm{Li}_{2} \mathrm{CO}_{3}} \\
& \mathrm{Li}_{2} \mathrm{CO}_{3}=\mathrm{\mu}_{\mathrm{Li}_{2} \mathrm{CO}_{3}}^{\circ}+\mathrm{RT} \ln \mathrm{X}_{\mathrm{Li}_{2} \mathrm{CO}_{3}}+\mathrm{RT} \ln \gamma_{\mathrm{Li}_{2}} \mathrm{CO}_{3} \text {. }
\end{aligned}
$$

Only the derivative is needed in this application, not $\mu$ itself nor the standard chemical potential $\mu^{\circ}$; these latter quantities are irrelevant and, unless the data are closely spaced and accurate, serious errors may occur because of extrapolation inherent in evaluating an integration constant. For systems with sparse data, errors arising from integration and subsequent differentiation can be avoided by evaluating the derivatives (numerlcally or graphically) directly from the data. For $\mathrm{Li}_{2} \mathrm{CO}_{3}-$ $\mathrm{K}_{2} \mathrm{CO}_{3}$ mixtures, the non-isothermal composition dependence of chemical 
potential of each component is available over a limited composition range from the liquidus temperature $\mathrm{T}_{\ell},(1)$ and the enthalpy of fusion $\mathrm{L}^{(2)}$. With the partial molal enthalpy of mixing $\overline{\mathrm{H}}^{\mathrm{E}}$, (4) the isothermal derivative $\left[(\partial \mu / \partial X)_{T}\right]_{T_{0}}$ at a temperature $\mathrm{T}_{0}$ may be obtained by means of equation (B), written for the case where neither solid solutions nor heat capacity terms are significant:

$\left[(\partial \mu / \partial \mathrm{X})_{\mathrm{T}}\right]_{\mathrm{T}_{\mathrm{o}}}=-\mathrm{T}_{\mathrm{o}}\left(\mathrm{L}+\overline{\mathrm{H}}^{\mathrm{E}}\right) \mathrm{dT}_{\ell}{ }^{-1} / \mathrm{dX}+\left(1-\mathrm{T}_{\mathrm{o}} \mathrm{T}_{\ell}^{-1}\right)\left[\left(\partial \overline{\mathrm{H}}^{\mathrm{E}} / \partial \mathrm{X}\right)_{\mathrm{T}}\right]_{\mathrm{T}}$

The derivatives of chemical potential of each component, obtained from (B) in the concentration range of its liquidus region, were calculated also for the concentration range given by the liquidus curve of the other component by means of the Gibbs-Duhem equation in its differential form. Interpolation of the derivatives for the mid-range of composition was also guided by the Gibbs-Duhem equation, i.e., the requirement that at $\mathrm{X}=0.5,\left(\partial \mu_{1} / \partial \mathrm{X}_{1}\right)_{\mathrm{T}}=\left(\partial \mu_{2} / \partial \mathrm{X}_{2}\right)_{\mathrm{T}}$.

Refinement of the calculations is proceeding and will be completed in the next quarter. The results to date indicate that the nonideality of these mixtures does not follow regular solution behavior and that the interaction parameter reported in the literature (and cited in ref. 3) for $\mathrm{Li}_{2} \mathrm{CO}_{3}, \mu^{\mathrm{k}} \mathrm{Li}_{2} \mathrm{CO}_{3} / \mathrm{X}^{\mathrm{L}} \mathrm{K}_{2} \mathrm{CO}_{3}$, is incorrect by a factor of 2 ; in the mid-range of compositions, the composition dependence of the excess chemical potentials is very close to that of the excess partial molal enthalpies. 
$\underline{\text { References }}$

(1) G. J. Janz and M. R. Lorenz, J. Chem. Eng. Data 6, 321 (1961).

(2) G. J. Janz, E. Neuenschwander and F. J. Kelly, Trans. Faraday Soc. 59, 841 (1963).

(3) B. K. Andersen and O. J. Kleppa, Acta Chem. Scand. A30, 751 (1976).

(4) J. Braunstein and C. E. Vallet, Proc. Symp. Electrode Materials and Processes for Energy Conversion and Storage, The Electrochemical Society, Princeton, NJ, 77-6, 559-571 (1977).

(5) J. Braunstein, H. R. Bronstein, J. I. Padova and C. E. Vallet, "Molten Carbonate Fuel Cell Program Progress Report for Periods Ending October 1-December 31, 1977; January 1-March 31, 1978," ORNL Rept. ORNL/TM-6168/V3. 
III. NiO Electrode Studies (H. R. Bronstein and J. Braunstein)

A tube furnace, gold boats, $\mathrm{CO}_{2}-\mathrm{O}_{2}$ gas mixtures and single crystal NiO samples have been assembled for investigation of the lithiation of NiO in $\mathrm{Li}_{2} \mathrm{CO}_{3}-\mathrm{K}_{2} \mathrm{CO}_{3}$ melts under controlled oxidizing and $\mathrm{CO}_{2}$ atmospheres. The single crystal NiO samples are wafers ground and polished to a thickness of about $0.1 \mathrm{~mm}$. Weight changes, chemical analysis and microprobe scanning will be employed to measure the extent of lithiation. 
ORNL/TM-6168/V4

Dist. Category UC-4

\section{DISTRIBUTION LIST}

\section{$\underline{\text { Interna1 }}$}

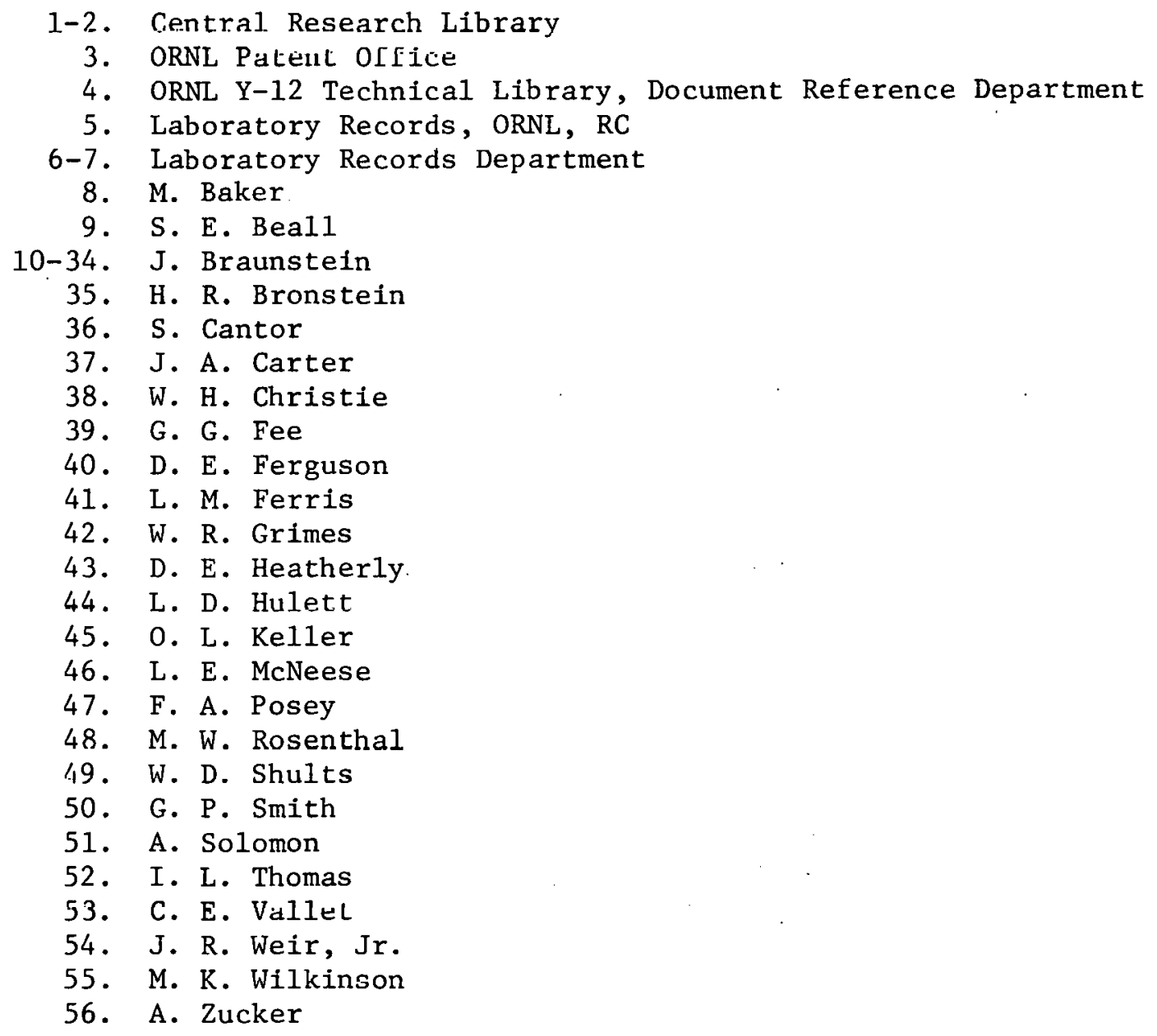

\section{External}

57. Dr. J. P. Ackerman, Argonne National Laboratory, Chemical Engineering Division, 9700 South Cass Avenue, Argonne, IL 60439.

58. Dr. B. S. Baker, Energy Research Corporation, 3 Great Pasture Road, Danbury, CT 06810.

59. Dr. T. R. Beck, Electrochemical Technology Corporation, 3935 Leary Way, NW, Seattile, WA 981.07.

60. Mr. P. L. Blum, DOE, 20 Massachusetts Avenue, NW, Washington, DC 20545.

61. Dr. A. Borucka, Borucka Research Company, 60 Chestnut Street, Livingston, NJ 07039. 
62. Dr. D. Chatterji, General Electric Company, PO Box 8, Building $\mathrm{K}-1$, Schenectady, NY 12301.

63. Dr. R. P. Epple, Material Sciences Program, Division of Basic Energy Sclences, DOE, Washington, DC 20545.

64. Mr. A. P. Fickett, Electric Power Research Institute, 3412 Hillview Avenue, PO Box 10412, Palo Alto, CA 94304.

65. Mr. J. Gracia, DOE, ORO.

66. Mr. E. Gillis, Electric Power Research Institute, 3412 Hillview Avenue, Po Box 10412, Palo Alto, CA 94304.

67. Dr. J. Giner, Giner, Inc., 144 Moody Street, Waltham, MA 02154.

68. Mr. R. Guidotti, Montana Energy and MHD Research and Development Institute, Inc., Po Box 380y, Butte, M'l 59701.

69. Mr. J. W. Ilarrison, General Electric Company DECP, 50 Fordham Ruad. Wilmington, MA U188\%.

70. Dr. J. Huff, U. S. Army Mobility Equipment Research and Development Center, Elcctrotechnology Branch, Ft. Belvoir, VA 22060.

71. Professor G. J. Janz, Rensselaer Polytechnic Institute, Cogswell Laboratory, Troy, NY 12181.

72. Dr. D. L. Johnson, Technological Institute, Department of Materials Science, Northwestern University, Evanston, IL 60201.

73. Mr. J. M. King, Power Systems Division, United Technology Corporation, PO Box 109, South Windsor, CT 06074.

74. Dr. A. R. Landgrebe, Branch Chief, Electrochemical Systems, Division of Energy Storage Systems, DOE, Washington, DC 20545.

75. Dr. L. G. Marianowski, Institute of Gas Technology, 3424 South State Street, Chicago, IL 60538.

76. Mr. L. Nanis, Stanford Research Institute, 333 Ravenswood Avenue, Menlo Park, CA 94025.

77. Dr. L. L. Radcliffe, DOE, ORO.

78. Dr. J. J, Rasmussen, Montana Energy and MHD Research Institute, PO Box 3809, Butte, MT 59701.

79. Professor J. R. Selman, Illinols Institute of Technology, TIT Center, Chicago, IL 60616.

80. Mr. R. Sperburg, DOE, San Francisco Operations Office, 1333 Broadway, Wells Fargo Bullding, Oakland, CA 94612.

81. Dr. S. Srinivasan, Brookhaven Nat1onal Laboratory, Department of Applied Science, Building 815, Upton, NY 11973.

82. Di. C. A. Trilling, Atomica Intcrnational Diviaion, Rockwoll International, 8900 De Soto Avenue, Canoga Park, CA 91304.

83. Dr. G. E. Voelker, DOE, 20 Massachusetts Avenue, NW, Washington, DC. 20545 .

84. Ms. J. Vought, Electrochimica Corporation, 2485 Charleston Road, Mountain View, CA 94040.

85. Mr. R. D: Weaver, Stanford Research Institute, 333 Ravenswood Avenue, Menlo Park, CA 94205.

86. Dr. K. Wray, Physical Sciences Tnc, 30 commerce Way, Woburn, MA 01801.

87. Professor E. Yeager, Case Western Reserve University, Electrochemistry Laboratory, University Circle, Cleveland, OH 44106.

88. Director of Research and Technical Support Division, DOE, ORO.

89-273. Given Distribution as shown in TID 4500 , UC-4 Chemistry. 